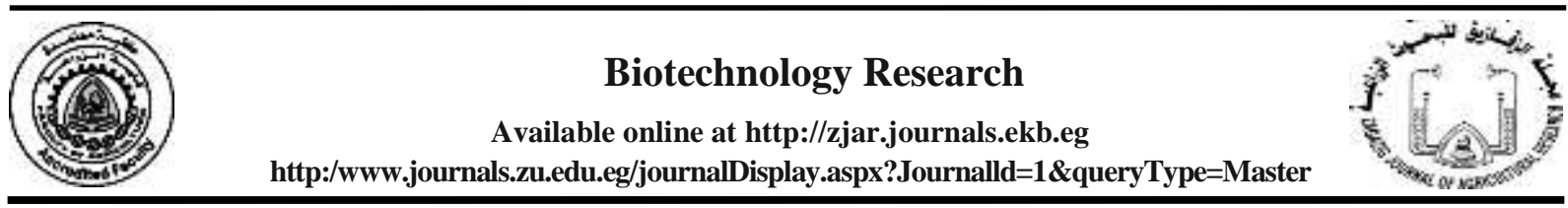

\title{
CHEMICAL COMPOSITION AND PHYTOCHEMICAL SCREENING OF Citrus sinensis (ORANGE) PEELS
}

\author{
Rabab E. Abdelazem ${ }^{1}$, H.T. Hefnawy ${ }^{* 1}$ and Gehan A. El-Shorbagy ${ }^{2}$ \\ 1. Biochem. Dept., Fac. Agric., Zagazig Univ., Egypt \\ 2. Food Sci. Dept., Fac. Agric., Zagazig Univ., Egypt
}

Received: 20/05/2021 ; Accepted: 24/06/2021

\begin{abstract}
To analyse qualitative and quantitative phytochemical and evaluate in vitro antioxidant properties of various alcoholic and aqueous extracts of Orange peel. Preliminary phytochemical analysis for alkaloids, cardiac glycosides, flavonoids, glycosides, phenols, resins, saponins, steroids, tannins, terpenoids and triterpenoids and quantitative phytochemical analysis for alkaloids, total phenolics, total flavonoids, tannins and saponins were made by following standard procedures. The quantitative phytochemical analysis of this species exhibited the presence of alkaloids, total phenolics, total flavonoids, tannins and saponins in considerable quantity.
\end{abstract}

Key words: Citrus sinensis, orange peels, chemical composition, phytochemical.

\section{INTRODUCTION}

Fruit peels have been a valuable source for maintaining human health. The use of fruit peel extracts for antimicrobial properties can be of great significance in therapeutic treatments (Lobo et al., 2010). Fruits by-products such as seeds, peels, stems, barks and leaves usually been discarded and currently the cause of a serious disposal problem in food and agricultural industries (Ghasemi et al., 2009). Therefore, extensive researches on utilizing these wastes are being carried out worldwide.

The peel was found to contain much higher beneficial compounds that possessed antioxidant capacities compared to other fruit parts ( Lim et al., 2006). The natural bioactive compounds in fruits such as carotenoids, quercetin derivatives, phenolic acids and saponins are originally found in the peels with higher concentration towards the flesh (Goulas and Manganaris 2012). Recent studies confirmed the substantially higher amount of phenolic compounds and ascorbic acids in the peel than in the pulp of most of the fruits.

\footnotetext{
* Corresponding author: Tel. :+ 201028377005

E-mail address: Hefnawytaha2014@gmail.com
}

The importance of natural bioactive compounds has led to the development of a large and potential market for natural sources in pharmaceutics and food products. Polyphenols in the plants considered to be free natural radical defense that were acknowledged to be beneficial for human health as an antioxidant, antitumor, and antimicrobial agent (Ighodaro, 2012).

Phytochemicals are non-nutritive in nature, which are found in plants and they have greater potential in curing many diseases. Some researchers have proved the existence of around 4000 phytochemicals (Mercy, 2015). Phytochemicals are grouped under many categories depending upon their basic chemical structure and its properties. Alkaloids, Anthocyanins, Flavonoids, Lignans, Phytosterols, Polyphenols, Terpenoids, Sapponins, etc. (Nanna et al., 2013) Amongst the arious phytochemicals listed Flavonoids and Polyphenols act as potent antioxidants (Saxena et al., 2012). Phenolics and favonoids are signified as the major antioxidant compounds in Allium sp. Ferulic acid, Coumaric acid, Sinapic acid, Isoquercitin etc., are the signifcant chemicals that had exhibited antioxidant potential in Allium sp. reported by Parvu et al. (2013). 
Orange peel is by products during the processing of fruit and studies show that they are good sources of bioactive compounds (Mamta and Parminder, 2013). Every year a large amount of oranges byproduct wastes are formed such as peels. During the production of orange juice and other orange products, the orange peel accumulates in the bulk and will produce environmental problem. Therefore, it is essential to find the applications for these peels. The orange peels are rich in nutrients and contain many phytochemicals; therefore they can be useful in many drugs and food items (Hegazy and Ibrahium, 2012). Citrus is the largest fruit crop in the world (100 million cubic tons per year) and the orange account for $60 \%$ (Oreopoulou and Tzia, 2006). The remaining orange peel account for approximately $45 \%$ of the total bulk (Yeoh et al., 2008). Consequently, significant amounts of orange peel are available as a by-product. The orange peel, if treated as waste materials, may create environmental problems, particularly water pollution, due to the presence of biomaterials such as essential oil (Ferhat, 2008) and pectin (Berna et al ., 2000).

An antioxidant can be broadly defined as any substance that delays or inhibits oxidative damage to a target molecule (Wang et al., 2006). The characteristic feature of an antioxidant is ability to scavenge the free radicals due to their redox hydrogen donators and singlet oxygen quencher (Emran et al., 2015). The free radicals can be scavenged by the natural (plants) and synthetic (butylated hydroxyl toluene, butylated hydroxyl anisol and tetra butyl hydro quinone) antioxidants (Lobo et al., 2010). But the usages of these synthetic antioxidants are now replaced because the natural antioxidants could be considered as safer without any side effects (Murray, 1998). In recent decades, many researchers are interested in medicinal plants for evaluation of antioxidant phytochemicals such as phenols, flavonoids and tannins which have received more attention for their potential role in prevention of human diseases (Sen et al., 2010). Antioxidant constituents of the plant material act as radical scavengers, and help in converting the radicals to less reactive species. Oxidation of biomolecules can cause generation of free radical in body. Natural antioxidants occur in all parts of plants. These antioxidants include carotenoids, vitamins, phenols, flavonoids (Dhanani et al., 2017). The objective of this research is to identify of the chemical composition, screening phytochemical and antioxidant activity from orange peels

\section{MATERIALS AND METHODS}

\section{Plant Materials}

Citrus sinensis, was purchased from market in Zagazig-Sharqiyah-Egypt. The peels were diced to smaller pieces after which the peels were shade-dried at room temperature (30$\left.35^{\circ} \mathrm{C}\right) .100 \mathrm{~g}$ of peels of oranges were coarsely powdered using a mortar and pestle and were further reduced to powder using an electric blender. The powder was dried in an oven at $40^{\circ} \mathrm{C}$ for $24 \mathrm{~h}$.

\section{Chemicals and Reagents}

The reagents used for the study include concentrated $\mathrm{H}_{2} \mathrm{SO}_{4}$, petroleum ether, $\mathrm{NaOH}$, Boric acid solution, Anhydrous $\mathrm{Na}_{2} \mathrm{SO}_{4}, \mathrm{CuSO}_{4}$, distilled water, $\mathrm{HCl}$, Wagner's reagent, Meyers reagent, Ferric chloride solution, Fehling's solution, Ethanol, Benzene, Ammonia solution, Methanol, Chloroform, Ethylacetate, Tannic acid, Folin-Denis reagent, $\mathrm{Na}_{2} \mathrm{CO}_{3}$, Lead acetate, Baljet reagent. All other chemicals and reagents used were of analytical grade and purchased from standard manufacturers.

\section{Proximate Analysis}

Moisture content, crude protein, total ash and crude fiber content were calculated by using AOAC Standard Method (2010). Moisture content was determined by an oven method. $5 \mathrm{gm}$ of sample placed in an oven at $105^{\circ} \mathrm{C}$ to a constant weight. Crude Protein was determined by the Kjeldahl method; Ash content was determined by using a muffle furnace maintained at $550^{\circ} \mathrm{C}$ for five hours.Crude fiber was obtained by digesting sample with $\mathrm{H}_{2} \mathrm{SO}_{4}$ and $\mathrm{NaOH}$ followed by incinerating in muffle furnace at $550^{\circ} \mathrm{C}$ for $4 \mathrm{hrs}$. Carbohydrate content was calculated from the difference of $100-[\%$ moisture $+\%$ ash $+\%$ protein $+\%$ fat $+\%$ fibre $]$.

\section{Method of Extraction}

Soxhlet extraction $10 \mathrm{~g}$ of powdered sample was weighed, packed and loaded in Soxhlet 
apparatus, attached with a condenser to carry out the process of extraction. Sample to solvent ratio was 1:10 and the extraction was carried out for 3-4 h to achieve 5-6 cycles. Two solvents chosen for the present study were double distilled water and ethanol. Solvent free crude extract prepared through lyophilization was used for further analysis.

Yield of the extract obtained was calculated as Yield $\%=$ yield production $/$ total sample $* 100$

\section{Digestion Procedure}

Two grams of the samples were weighed into Kjeldahl's flask mixed with $20 \mathrm{ml}$ of concentrated $\mathrm{H}_{2} \mathrm{SO}_{4}$ and Helder tablet. The flask was then heated at $70^{\circ} \mathrm{C}$ for $40 \mathrm{~min}$ and then, the heat was increased to $120^{\circ} \mathrm{C}$. The mixture was turned to black after a period of time. Digestion was completed after the solution became clear and white fumes appeared. The digest was diluted with $20 \mathrm{ml}$ of distilled water and boiled for $15 \mathrm{~min}$. The solution was then allowed to cool, it was then transferred into $100 \mathrm{ml}$ volumetric flasks and diluted to the mark with distilled water. The sample solution was then filtered through a Whatman filter paper No. 1 into a screw-capped polyethylene bottle, the procedure was repeated for all samples.

\section{Determination of Minerals}

The method applied for the assessments of mineral concentration in samples after digestion was by using the Atomic Absorption Spectrophotometric (AAS) technique (Analyst 200, Perkin Elmer, Waltham, MA, USA) as described previously (Roghini and Vijayalakshmi, 2018).

\section{Fourier Transform Infrared Spectroscopy (FT-IR)}

Spectra analysis Infrared spectra of freezedried orange peel powder was recorded on a Perkin Elmer FT-IR Spectrum 100 fitted with an ATR accessory (Wallace et al., 2014). To powdered sample of extract were loaded on the sample chamber of FT-IR spectrophotometer and scanned at room temperature $\left(25 \pm 2^{\circ} \mathrm{C}\right)$ with a scan range from 500 to $4000 \mathrm{~cm}^{-1}$ at a resolution of $2 \mathrm{~cm}^{-1}$.

\section{Phytochemical screening}

Qualitative assay, for the presence of plant secondary metabolites such as reducing sugar, saponnins, anthracene glycosides, deoxysugar cardiac glycosides, tannins, flavonoids and alkaloids were carried out on the extract of the Citrus sinensis peels following standard procedure (Harbone, 1973; Trease and Evans, 2003).

\section{Preparation of extracts}

Aqueous and alcoholic extracts of orange peels were prepared by soaking $3.0 \mathrm{~g}$ of dried rind and $5.0 \mathrm{~g}$ of dried aril in $80 \mathrm{~mL}$ distilled water, separately, for 24 hours, followed by fltration.

Chloroform and petroleum ether extracts of orange peels were prepared by soaking $0.5 \mathrm{~g}$ of dried rind and $0.5 \mathrm{~g}$ of dried aril in $5 \mathrm{~mL}$ chloroform, separately, for 24 hours, followed by fltration.

\section{Quantification of total phenols}

The amount of total phenols in peel crude extracts was determined by Folin Ciocalteu (FC) method as modified by Singleton and Rossi (1965). Gallic acid (GA, 5\%) from Sigma was used to construct a calibration curve. Ten $\mu 1$ extracts were placed in test tubes. Then $0.5 \mathrm{ml}$ of $\mathrm{FC}$ reagent were added and waited for $4 \mathrm{~min}$. one milliliter of $\mathrm{Na}_{2} \mathrm{CO}_{3}(7.5 \%$, W/V) was added, and kept for $2 \mathrm{~h}$ in darkness and finally the absorbance of each sample was measured at $760 \mathrm{~nm}$.

\section{Total flavonoid content}

Total flavonoid content was measured by the aluminium chloride colorimetric $\left(\mathrm{AlCl}_{3}\right)$ method (Lee et al., 2012). Ten microliters of each extract was added to $100 \mu \mathrm{l}$ of sodium nitrite $(5 \%, \mathrm{~W} / \mathrm{V})$ and allowed to stand for $5 \mathrm{~min}$. then $100 \mu \mathrm{AlCl}_{3}(10 \%$, W/V) were added and incubated for $5 \mathrm{~min}$, followed by the addition of $1 \mathrm{ml}$ sodium hydroxide $\mathrm{NaOH}(1 \mathrm{M})$ and volume was made up to $5 \mathrm{ml}$ with distilled water. After $15 \mathrm{~min}$, the solution was mixed completely and the absorbance was measured against blank at $510 \mathrm{~nm}$. Total flavonoid content was expressed as $\mu \mathrm{g}$ Catechin (BOH chemicals ltd., poole, England) equivalent (CE) per ml of crude extract.

\section{Total alkaloids determination}

Bromocresol green (BCG, Aldrich chemicals) dye was used to estimate total alkaloids (Shamsa et al., 2008). BCG solution was prepared by 
heating $69.8 \mathrm{mg} \mathrm{BCG}$ with $3 \mathrm{ml} \mathrm{NaOH}(2 \mathrm{~N})$ and $5 \mathrm{ml}$ of distilled water until completely dissolving. The solution was then completed to 1 liter with distilled water. Ten microliters of the crude extracts were thoroughly mixed with $3 \mathrm{ml}$ of BCG solution. Thirty minutes later, $5 \mathrm{ml}$ of chloroform were added, and shaken for $2 \mathrm{~min}$. The lower layer was separated after $30 \mathrm{~min}$. The extraction was continued for three times. A set of reference standard solutions of $0.1 \%$ atropine (Merck, Dermstadt) was prepared, and followed the steps described above. The absorbance of color was read at $418 \mathrm{~nm}$. The total alkaloid content was expressed as Atropine equivalent (AE)/gm crude extract.

\section{Estimation of tannins content}

Tannins content of orange peels was estimated by the method of Siddhuraju and Manian (2007). A total of $500 \mu \mathrm{L}$ of the extracts were taken in test tube separately and treated with 100 $\mathrm{mg}$ of polyvinyl polypyrrolidone and $500 \mu \mathrm{L}$ of distilled water. This solution was incubated at $4^{\circ} \mathrm{C}$ for $4 \mathrm{~h}$. Then the sample was centrifuged at $5000 \mathrm{rpm}$ for $5 \mathrm{~min}$ and $20 \mu \mathrm{L}$ of the supernatant was taken. This supernatant has only simple phenolics free of tannins (the tannins would have been precipitated along with the polyvinyl polypyrrolidone). The phenolics content of the supernatant was measured at 725 $\mathrm{nm}$ and expressed as the content of free phenolics on a dry matter basis. From the above results, the tannins content of the extract was calculated as follows:

Tannins $(\mathrm{mg}$ GAE$/ g$ extract $)=$ Total phenolics (mg GAE/g extract)-Free phenolics (mg GAE/g extract)

\section{Estimation of total saponins content}

Estimation of total saponins content was determined by the method described by Makkar et al. (2007). Based on vanillinsulphuric acid colorimetric reaction with some modifications. About $50 \mu \mathrm{L}$ of plant extract was added with $250 \mu \mathrm{L}$ of distilled water. To this, about $250 \mu \mathrm{L}$ of vanillin reagent $(800 \mathrm{mg}$ of vanillin in $10 \mathrm{~mL}$ of $99.5 \%$ ethanol) was added. Then $2.5 \mathrm{~mL}$ of $72 \% \mathrm{H}_{2} \mathrm{SO}_{4}$ was added and it was mixed well. This solution was kept in a water bath at $60{ }^{\circ} \mathrm{C}$ for $10 \mathrm{~min}$. After $10 \mathrm{~min}$, it was cooled in ice cold water and the absorbance was read at $544 \mathrm{~nm}$. The values were expressed as diosgenin equivalents (mg DE/g extract) derived from a standard curve.

\section{Statistical Analysis}

All the results were expressed as mean values \pm standard deviation. Comparisons will be performed by analysis of variance (ANOVA). Statistical analyses will be run using SPSS V. 6.0 software. The correlations among the data were calculated using Pearson's correlation coefficient (r) and $P<0.05$ was considered significantly different.

\section{RESULTS AND DISCUSSION}

\section{Proximate Composition of Orange Peel Powder}

The results obtained for the compositional content of protein, fat, carbohydrate, energy value, moisture, ash and $\mathrm{pH}$ of orange peel are shown in Fig.1. The moisture content of the shade dried powdered sample was found to be $9.2 \%$. Protein Content was found to be $12 \%$ on dry weight basis (DW). This implies that the orange peel may also be a source of important nutrients. The carbohydrate value was obtained via difference i.e. $100-($ Values of ash + crude fiber + protein + fat + Moisture content). The above values are expressed as \% by weight.

These results are consistent with that was mentioned by Sulekha and Jaya (2018) since they made a preliminary analysis of orange peel residue, and the obtained results were as follows: moisture (9.0\%), protein (13.2\%), crude fat $(6.8 \%)$, fiber $(15.3 \%)$, ash $(7.8 \%)$ and carbohydrate $(48.9 \%)$.

\section{Minerals Content of Orange Peels}

The data presented in Table 1 show the minerals content of orange peels. Calcium, nitrogen, phosphorus, potassium, sodium, manganese, copper, zinc and iron were detected. The results also showed that the calcium and potassium content of orange peels was larger amount (1340 and $480 \mathrm{mg} / 100 \mathrm{~g}$ ) followed by nitrogen $(230 \mathrm{mg} / 100 \mathrm{~g})$. At the same time, sodium and phosphorus content was found in moderate amounts $(55$ and $51 \mathrm{mg} / 100 \mathrm{~g}$ ). In addition, it contained the lowest amount of iron, 


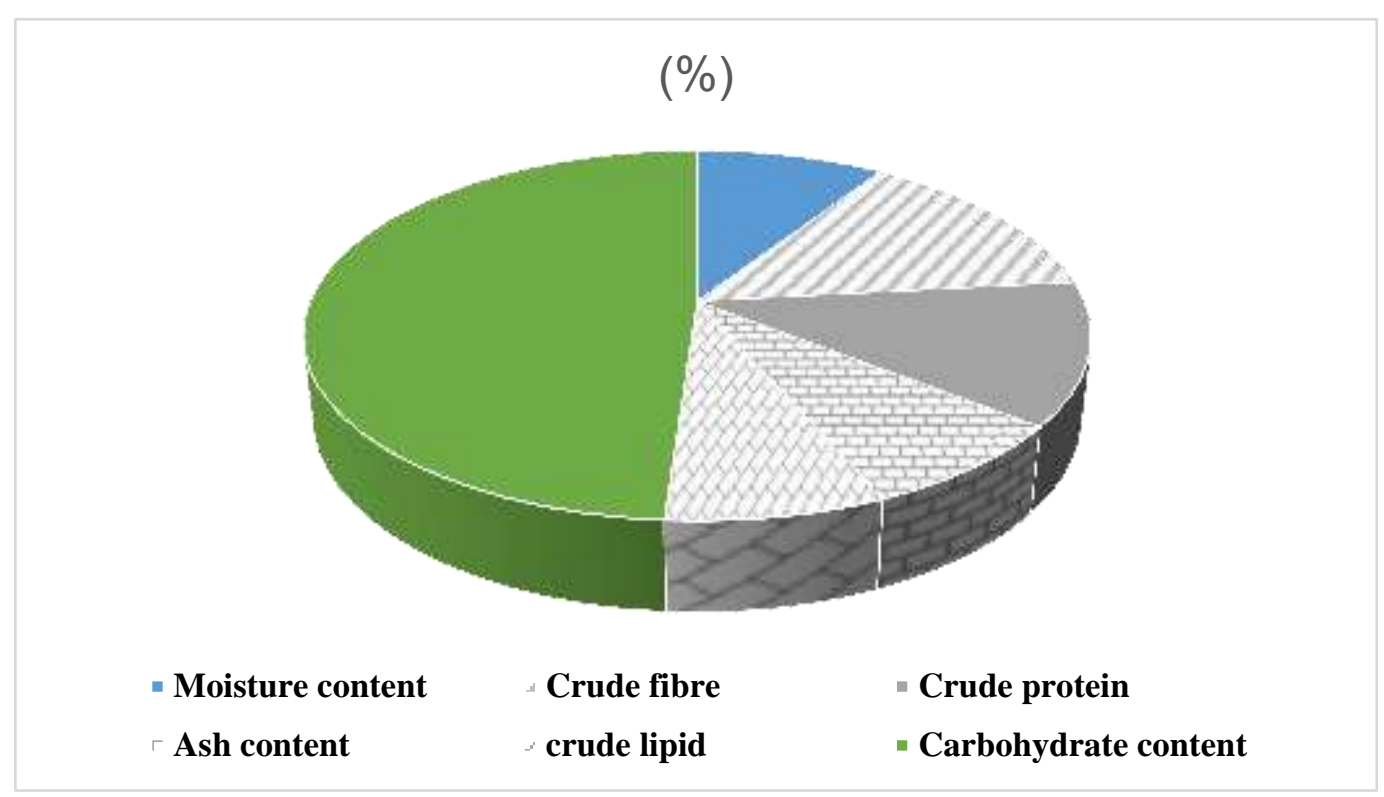

Fig. 1. Proximate analysis of orange peel

Table 1. Minerals content $(\mathrm{mg} / 100 \mathrm{~g})$ of orange peels

\begin{tabular}{lccccccccc}
\hline Sample & \multicolumn{10}{c}{ Minerals (mg/100g) } \\
\cline { 2 - 11 } & $\mathbf{C a}$ & $\mathbf{N}$ & $\mathbf{P}$ & $\mathbf{K}$ & $\mathbf{N a}$ & $\mathbf{M n}$ & $\mathbf{C u}$ & $\mathbf{Z n}$ & $\mathbf{F e}$ \\
\hline Orange peels & 134 & 230 & 51 & 480 & 55 & 0.40 & 3.27 & 0.30 & 9.37 \\
\hline
\end{tabular}

* Calculated on dry weight basis.

copper, zinc and manganese. These results agree with those recorded by Roghini and Vijayalakshmi (2018) and Barros et al. (2012). The mineral content of plants can be significantly influenced by variety, location and environmental conditions (Osagie and Eka, 1998).

The importance of minerals in normal nutrition and metabolism cannot be overemphasized. The mineral composition of fruits largely depends on many factors such as soil type, stage of maturity, variety of cultivars, topography, and other geographical factors.

\section{Extraction of Orange Peel Extract by Using Various Solvents}

Table 2 shows the percentage of yield of crude successive extracts (petroleum ether, chloroform, ethanol, methanol and water) of orange peels. The soxhlet extraction of the orange peel using various solvents showed different yield in each experiment of this research study (Siddhuraju and Becker, 2003) Yield of extract differs from solvent to solvent. By using Methanol as a solvent we got $22.6 \%$ yield which is higher as compared to other solvents. Hexane and chloroform gave poor yield respectively $2.8 \%$ and $3.2 \%$. Aqueous and ethanol extraction of the orange peel gave $6.7 \%$ and $15.4 \%$ yield, respectively. Fig. 2 yield of Orange peel extract by different solvent using soxhlet extractor (Kumar et al., 2011).

\section{Phytochemical Screening of the Orange Peel Extract}

The present study revealed that the various alcoholic and aqueous extracts of orange peel contained alkaloids, cardiac glycosides, flavonoids, glycosides, phenols, resins, saponins, steroids, tannins, terpenoids and triterpenoids (Table 2). However, phenols were detected only in methanolic extracts of both parts and the cardiac glycosides were found in root extracts of the solvents chloroform, ethyl acetate and methanol. 
Table 2. Preliminary qualitative phytochemical analysis of various alcoholic and aqueous extracts of orange peel

\begin{tabular}{lccccc}
\hline Plant constituents & Petroleum ether & Chloroform & Ethyl acetate & Methanol & Water \\
\hline Alkaloids & - & + & - & +++ & + \\
Cardiac glycosides & + & - & - & + & + \\
Flavonoids & - & - & + & +++ & +++ \\
Glycosides & - & - & + & +++ & \\
Phenols & - & - & - & +++ & - \\
Resins & - & + & + & + & + \\
Saponins & - & + & - & +++ & - \\
Steroids & - & - & - & +++ & ++ \\
Tannins & + & - & - & +++ & - \\
Terpenoids & - & - & - & +++ & ++ \\
Triterpenoids & - & + & & + & ++ \\
\hline
\end{tabular}

+++: highly present, ++: moderately present, +: Low, -: absent.

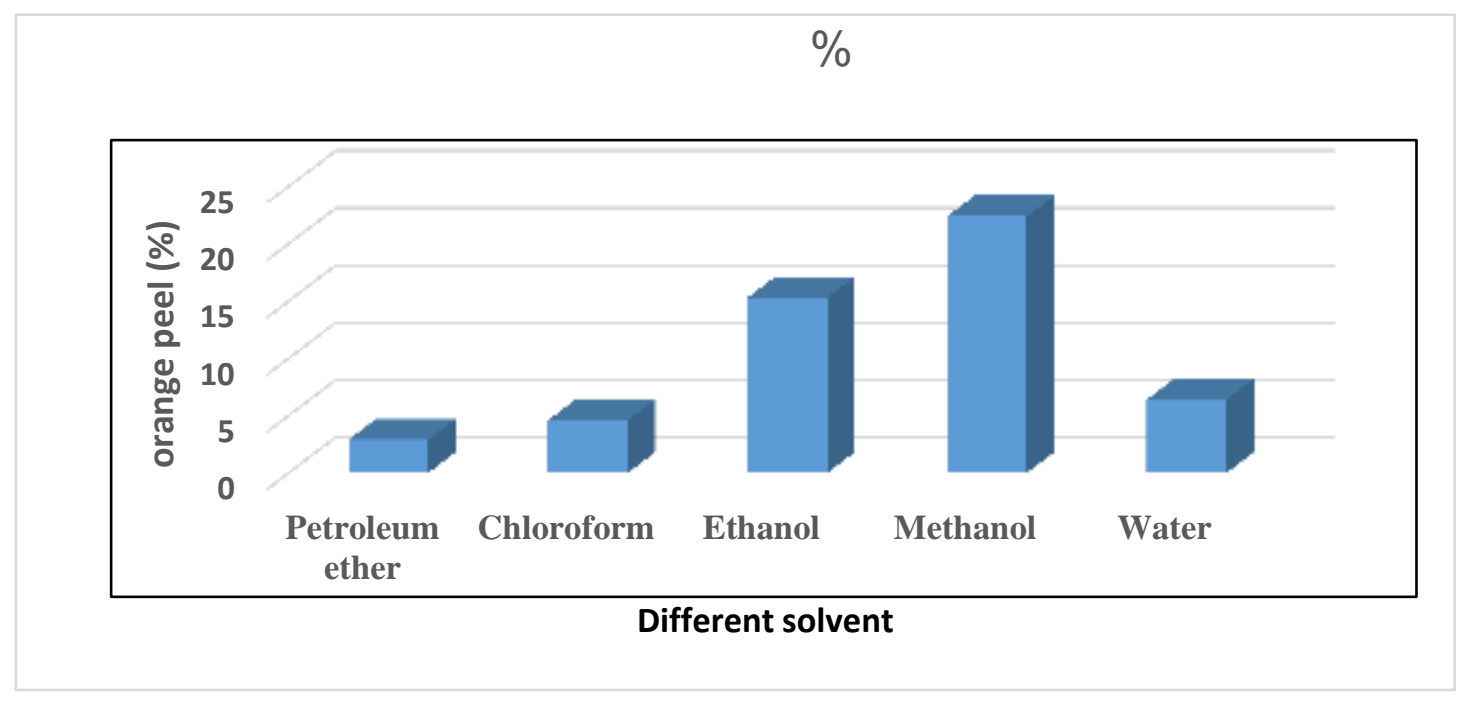

Fig. 2. Yield of Orange peel extract by different solvent

Next to methanol extract, ethyl acetate extracts of orange peel showed the presence of rich variety of secondary metabolites. Petroleum ether, chloroform and water extracts showed the less variety of these secondary metabolites. Compared to all other solvent extracts, methanolic leaf and root extracts had higher number of secondary metabolites with high degree of precipitation (+++). Triterpenoids and resins were determined to be present with lesser amount (+) only in all extracts.

Preliminary qualitative phytochemical analysis made for orange peel revealed the presence of alkaloids, cardiac glycosides, flavonoids, glycosides, phenols, resins, saponins, steroids, tannins, terpenoids and triterpenoids. These secondary metabolites are reported to have many 
biological and therapeutic properties (Gul et al., 2017), the extraction yield calculated for petroleum ether, chloroform, ethyl acetate, methanol and water extracts of orange peel showed that methanol extract registered higher percentage of yield. It may be due to high polarity of methanolic solvent which can draw high variety of plant constituents than the other solvents did (Manivannan et al., 2016). Generally, majority of the secondary metabolites studied, flavonoids and saponins were rich in ethyl acetate extracts. It is explained that the polarity level and species nature are playing major role in extracting the secondary metabolites (Pooja and Vidyasagar, 2016). The biological property, antioxidant activity was determined to be effective through various assays for orange peel.

Phytochemicals are non-nutritive plant chemicals possessing varying degrees of diseasepreventive properties. They are invaluable sources of raw materials for both traditional and orthodox medicine. Phytochemicals may display their health-protective effects in diverse ways. They can act as antioxidants and protect cells against free radical damage, e.g. polyphenols, carotenoids etc. (Omoregie and Osagie, 2012). They may also help in reducing risk for cancer by inhibiting tumor production (Devasagayam et al., 2004). Other modes of action are via antibacterial activity and hormonal stimulation (Mathew et al., 2012). The citrus peels are rich in nutrients and contain many phytochemicals with strong potential for use in drug production or as food supplements (Chede et al., 2013). The obtained results are in agreement with these assertions as a range of phytochemicals viz; alkaloids, terpenoids, tannins, flavonoids, saponins, cardiac glycosides, steroids were detected in the orange peels and seeds extracts.

Phytochemical screening of the peel powder extract of citrus peel shows the present Saponin of which are steroid or saponin. Triterpenoid glycoside characterized by their bitter or astringent taste, forming properties and hemolytic effect on red blood cells (Gul et al., 2017). Saponin possess both of beneficial (cholesterol-lowring) and deleterious (cytotoxic permeabilization of the intestine) properties and also exibite structure dependent biological activities. Saponin cause reduction of blood cholesterol by preventing its reabsorption which make it useful in cardiovascular disease (Lawal et al., 2013). In addition, it has been documented that saponin have antitumor and antimutagenic activity and can lower risk of human cancer cell from growing saponin are belived to react with the cholesterol rich membranes of cancer cell, thereby limiting their growth and visibility plants produce saponin has potential to fight infection by parasites and in humans saponin serves as immune system booster and also protect against viruses and bacteria (Roghini and Vijayalakshmi, 2018).

The non sugar part of saponins has direct antioxidant activity which may result in reduced risk of cancer and heart disease. Flavonoids are also responsible for the colouring of fruits, vegetable and Herbs. Alkaloid are very important in medicine and constituent most of the valuable drugs. They have marketed physiological effect on animal. Okwu and Josiah (2006) have documented and important of tannin in promoting wound healing. Iwu (1983) have also reported that tannin containing antidiabetic properties. The presence of phenol in citrus peel serves as antiseptic and reduces inflammation when taken internally.

\section{FT-IR spectral analysis}

FT-IR spectral analysis data for orange peel revealed the existence of multiple functional groups in the extracts. The spectral features of the extract were shown in Fig. 3. For all extracts, the very strong absorption bands were observed at $3603.8 \mathrm{~cm}^{-1}$ of orange peel, could be attributed to $\mathrm{N}-\mathrm{H}$ stretching of proteins and $\mathrm{O}-\mathrm{H}$ stretching of carbohydrates and water, which indicate hydroxyl groups existed in all extracts. The bands at $2112.8, \mathrm{~cm}^{-1}$ of orange peel was due to the $-\mathrm{C} \equiv \mathrm{C}-$ group. The bands between the wave numbers of $1800-750 \mathrm{~cm}^{-1}$ reflected the biochemical compositions, especially the moieties of carbohydrate, lipid, protein and polyphenols in plant. The absorptions around $1669.3 \mathrm{~cm}^{-1}$ could be assigned to ring $\mathrm{C}-\mathrm{C}$ stretch of phenyl ( $\mathbf{L u}$ et al., 2011), which is present at high levels in the polyphenolic components of orange peel. Absorptions peak at $1407.1 \mathrm{~cm}^{-1}$ for orange peel, corresponding to 
Table 3. Total phenolics, total flavonoids, and tannins contents of various alcoholic and aqueous extracts of orange peel

\begin{tabular}{ccccc}
\hline Sample & Total phenolics & Total flavonoids & Tannins & Saponins \\
\hline PE & $0.77 \pm 0.01$ & - & $0.17 \pm 0.02$ & $13.1 \pm 0.06$ \\
CH & $0.45 \pm 0.02$ & - & $0.12 \pm 0.03$ & $12.8 \pm 0.02$ \\
EA & $0.11 \pm 0.04$ & $0.79 \pm 0.09$ & $0.03 \pm 0.01$ & $0.6 \pm 0.02$ \\
ME & $3.75 \pm 0.01$ & $12.84 \pm 0.08$ & $1.61 \pm 0.05$ & $16.2 \pm 0.02$ \\
WA & $0.32 \pm 0.03$ & $16.68 \pm 0.1$ & $14.07 \pm 0.02$ & $13.4 \pm 0.01$
\end{tabular}

Values were performed in triplicates and represented as mean \pm SD. PE: petroleum ether, CH: chloroform, ET: ethanol, ME: methanol, WA: water, -: not detected.

Mean values followed by different superscript in a column are significantly different $(P<0.05)$.

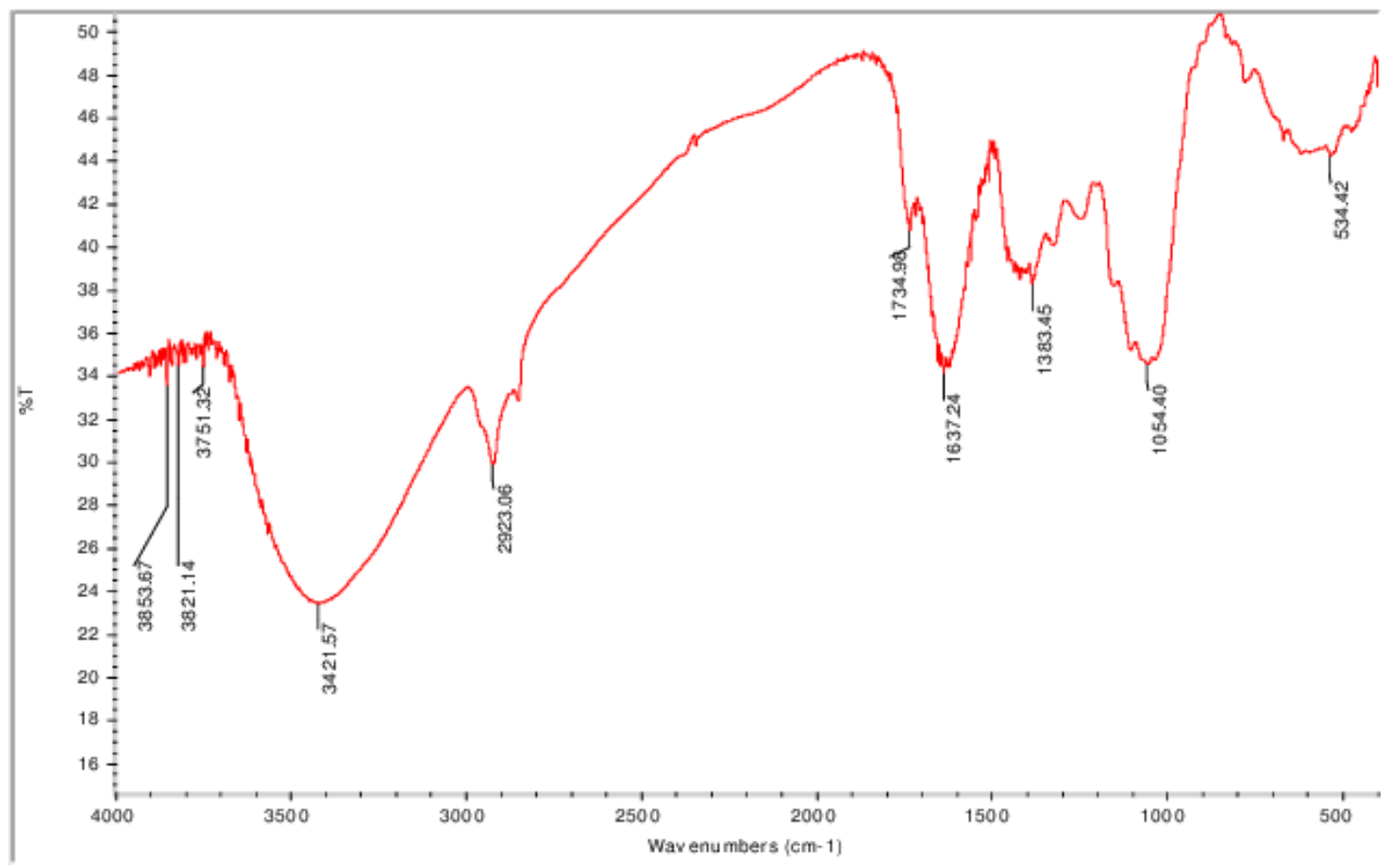

Fig. 3. The FTIR spectrum of the orange peel powder

$\mathrm{CH}_{3}$ asymmetric deformation (Agarwal et al., 2006). The minor bands obtained at $1261.7 \mathrm{~cm}^{-1}$ from orange peel, were ascribed to $\mathrm{O}-\mathrm{H}$ $(-\mathrm{COOH})$ variable angle vibration (Zhao et al., 2014). The wavenumber region between 1200 and $950 \mathrm{~cm}^{-1}$ contains functional groups mainly from carbohydrates, while absorption peak at $1034.3 \mathrm{~cm}^{-1}$ are attributed of $-\mathrm{CH}_{2} \mathrm{OH}$ groups of carbohydrates (Lu et al., 2011). The various functional groups observed in orange peel reflected the biochemical compositions, especially the phenolic compounds, carboxylic acids, alcohols, carbohydrates, and proteins in the plant, responsible for several medicinal properties and biological activities which is confrmed by our investigation in chemical composition. The presence of phytochemicals carrying hydrogen functional group - $\mathrm{OH}$ bonded found that the hydroxyl functionality is an integral part of most of phenolic phytochemicals 
such as polyphenols and flavonoids to provide a relative ranking of extracts in term of antioxidant activity. Therefore, the presence of characteristic functional groups that are responsible for various medicinal properties may be influence considerably the biological properties and contribute signifcantly to their solubility, partition coefcient, stereochemistry and inherent acidbase properties (Knittel and Zavod, 2008).

\section{Conclusion}

Based on the chemical composition of orange peels, the crude fibre and protein of orange peels can serve as non-caloric bulking agents. Phytochemical analysis of Orange peel extract showed the presence of tannins, terpenoids, flavonoids and saponins. Antraquiones were ompletely absent in both the method extract. The most common technique used to obtain the extracts with the antioxidant activity is the extraction using organic solvent. The extraction of the orange peel with methanol and hexane was efficient in extracting the phytochemical compounds Methanol is effective than other solvents for extracting orange peel extract. This study was focused on waste minimization in fruit juice processing industry. The various functional groups observed in the di-erent extracts probably confrmed by FT-IR analysis indicate the richness of orange peels in polyphenols. The orange peel powder which has an excellent aroma can be incorporated into various recipes to enhance the flavour, taste and nutritive value of recipes.

\section{REFERENCES}

Agarwal, R., P. Tandon and V.D. Gupta (2006). Phonon dispersion in poly (dimethylsilane). J of Organometallic Chem., 691 (13) : 29022908.

AOAC (2010). Association of Official Analytical Chemists $.17^{\text {th }}$ Ed USA; DC.

Barros, H.R., T.A. Castro Ferreira and M.I. Genovese (2012). Antioxidant capacity and mineral content of pulp and peel from commercial cultivars of citrus from Brazil. Food Chem., 134:1892-1898.

Berna, A., A. Tàrrega, M. Blasco and S. Subirats (2000). Supercritical $\mathrm{CO}_{2}$ extraction of essential oil from orange peel; effect of the height of the bed. J. Supercritical Fluids, 18: 227-237.

Chede, P.S. (2013). Phytochemical analysis of Citrus sinensis peel. Int. J. Pharm. Biol. Sci., 4 (1): 339-343.

Devasagayam, T.P.A., J.C. Tilak, K.K. Boloor, K.S. Sane and S.S. Ghaskadbi (2004). Free Radicals and Antioxidants in Human Health: Current Status and Future Prospects. JAPI, 52: 794-804.

Dhanani, T., S. Shah, N.A. Gajbhiye and S. Kumar (2017). Effect of extraction methods on yield, phytochemical constituents and antioxidant activity of Withania somnifera. Arab. J Chem., 10: 1193-1199.

Emran, T.B., M.N. Mir, A. Rahman, U. Zia and M. Islam (2015). Phytochemical, Antimicrobial, Cytotoxic, Analgesic and Anti-inflammatory Properties of Azadirachta indiaca: A Therapeutic Study. J. Bioana. and Biomed., 12: $1-7$

Ferhat, M.A., B.Y. Meklati, F. Visinoni, M. AbertVian and F. Chemat (2008). Solvent free microwave extraction of essential oils Green chemistry in the teaching laboratory. Chimica Oggi., 26: 48-50.

Ghasemi, K., Y. Ghasemi and M. Ebrahimzadeh (2009). Antioxidant activity, phenol and flavonoid contents of 13 citrus species peels and tissues. Pak. J. Pharm. Sci., 22: 277-281.

Goulas, V. and G. Manganaris (2012). Exploring the phytochemical content and the antioxidant potential of Citrus fruits grown in Cyprus. Food Chem., 131:39-47.

Gul, R., S.U. Jan, F. Syed, F. Sherani and J. Nusrat (2017). Preliminary Phytochemical Screening, Quantitative Analysis of Alkaloids, and Antioxidant Activity of Crude Plant Extracts from Ephedra intermedia Indigenous to Balochistan. The Sci. World J., 1-7.

Harbone, J.R. (1973). Phytochemical methods: A guide to modern techniques of plant analysis; Chapman and Hall Ltd London, 49188.

Hegazy, A.E. and M.I. Ibrahium (2012). Antioxidant activities of orange peel Extracts, World Appl. Sci. J., 18 : 684-688 
Ighodaro, O. (2012). Evaluation study on Nigerian species of Musa paradisiaca peels: phytochemical screening, proximate analysis, mineral composition and antimicrobial activities. Res., 4: 17-20.

Iwu, M.M. (1983). Hypoglycemic properties of Bridelia furruginear leaves. Fitoterapia., 54: 243 -248.

Knittel, J.J. and R.M. Zavod (2008). Drug design and relationship of functional groups to pharmacologic activity. In T.L. Lemke and D. A. Williams (Eds.), Foye's principles of medicinal chemistry. New York: Lippincott Williams \& Wilkins, $6^{\text {th }}$ Ed., 26-53.

Kumar, K., A. Narayani and S. Jayakumar (2011). Antimicrobial Activity and Phytochemical Analysis of Citrus Fruit Peels -Utilization of Fruit Waste. Int. J. Eng. Sci. and Technol. (IJEST), 3 (6): 5414-5421.

Lawal, D., J.A. Bala, S.Y. Aliyu and M.A. Huguma (2013). Phytochemical screening and in vitro anti-bacterial studies of the ethanolic extract of Citrus sinensis (Linn.) peel against some clinical bacterial isolates. Int. J. Innov. Appl. Stud., 2(2): 138-145.

Lee, W.H. and S.I. Intan (2012). Antioxidant activity, total phenolics and total flavonoids of Syzygium polyanthum (Wight) Walp leaves. Int. J. Med. Arom. Plants, 2 (2): 219228.

Lim, Y., T. Lim and J. Tee (2006). Antioxidant properties of guava fruit: comparison with some local fruits. Sunway Acad. J., 3: 9-20.

Lobo, V., A. Patil, A. Phatak and N. Chandra (2010). Free radicals, antioxidants and functional foods: Impact on human health. Pharm. Rev., 4: 118-126.

Lu, X., J. Wang, H.M. Al-Qadiri, C.F. Ross, J.R. Powers, J. Tang and B.A. Rasco (2011). Determination of total phenolic content and antioxidant capacity of onion (Allium cepa) and shallot (Allium oschaninii) using infrared spectroscopy. Food Chem., 129: 637-644.

Makkar, H.P., P. Siddhuraju and K. Becker (2007). Methods in molecular biology: plant secondary metabolites. Totowa: Human Press., 93-100.
Mamta, A. and P. Kaur (2003). Phytochemical screening of orange peel and pulp. Int. J. Res. Eng. and Technol., 2 (12): 517-522.

Manivannan, A., P. Soundararajan, Y.G. Park and B.R. Jeong (2016). Chemical elicitorinduced modulation of antioxidant metabolism and enhancement of secondary metabolite accumulation in cell suspension cultures of Scrophularia kakudensis Franch. Int. J. Mol. Sci., 17: 399.

Mathew, B.B., S.K. Jatawa and A. Tiwari (2012). Phytochemical Analysis of Citrus Limonum pulp and peel. Int. J. Pharm. Pharm. Sci., 4 (2): 269-371.

Murray, A. (1998). Dietary reference intake for antioxidant nutrients. J. Ame. Dietetic Ass., 100:637-640.

Okwu, D.E. and C. Josiah (2006). Evaluation of the chemical composition of two Nigerian medicinal plants. Afr. J. Biotechnol., 5 (4): 357-361.

Omoregie, E. and A. Osagie (2012). Antioxidant Properties of methanolic extracts of some Nigerian Plants on Nutritionally-Stressed Rats. Nig. J. Basic. Appl. Sci., 20 (1): 7-20.

Oreopoulou, V. and C. Zia (2006). Utilization of plant by-products for the recovery of proteins, dietary fibers, antioxidants and colorants. In Utilization of by-Yeoh products and treatment of waste in the food industry, Springer.

Osagie, A.U. and O.U. Eka (1998). Mineral elements in plant foods. In: Nutritional quality of Plant foods. Ambik press, Benin City, Edo State, Nigeria, 8 - 86.

Parvu, M., A. Toiu, L. Vlase and E.A. Parvu (2013). Determination of some polyphenolic compounds from Allium species by HPLCUV-MS. Nat. Prod. Res., 24: 1318-1324.

Pooja, S. and G.M. Vidyasagar (2016). Phytochemical screening for secondary metabolites of Opuntia dillenii Haw. J. Med. Plants Studies, 4(5):39-43

Roghini, R. and K. Vijayalakshmi (2018). Phytochemical screening, quantitative analysis of flavonoids and minerals in ethanolic extract of Citrus paradisi. Int. J Pharm. Sci. and Res., 9 (11): 4859-4864. 
Saxena, M., J. Saxena and A. Pradhan (2012). Flavonoids and phenolic acids as antioxidants in plants and human health. Int. J. Pharm. Sci. Rev. Res., 16: 130-134.

Sen, S., R. Chakaraborty, C. Sridhar, Y. Reddy and D. Biplab (2010). Free radicals, antioxidants, diseases and phytomedicines: current status and future prospect. Int. J. Pharm. Sci. Rev. Res., 3(1): 91- 100.

Siddhuraju, P. and K. Becker (2003). Antioxidant properties of various solvent extracts of total phenolic constituents from three different agroclimatic origins of drumstick tree (Moringa oleifera Lam.) leaves. J. Agric. Food Chem., 51 (8): 2144-2155.

Singleton, V. and J.A. Rossi (1965). Colorimetry of total phenolics with phosphomolybdic phosphotungstic acid reagents. Ame. J. Enol. Viticult, 16 (3): 144-158.

Sulekha, G. and G. Jaya (2018). Orange Peel: A Potential Source of Phytochemical Compounds Int. J. Chem. Tech. Res., 11 (02): 240-243.

Trease, G.E. and W.C. Evans (2003). Textbook of Pharmcognosy Elsevier Publication. $13^{\text {th }}$ Ed., 345-356.

Wallace, J.M., P.J. Puskar and F. Bégué (2014). Advances in Fourier transform infrared spectroscopy of natural glasses: from sample preparation to data analysis. Lithos, 206: 5264.

Wang, B-S., S-S. Lin, W-C. Hsiao, J-J. Fan, LF. Fuh and P-D. Duh (2006). Protective effects of an aqueous extract of Welsh onion green leaves on oxidative damage of reactive oxygen and nitrogen species. Food Chem., 98: 149-157.

Zhao, H., Q. Wang, Y. Sun, B. Yang, Z. Wang, G. Chai, Y. Guan, W. Zhu, Z. Shu, X. Lei and H. Kuang (2014). Purification, characterization and immunomodulatory effects of Plantago depressa polysaccharides. Carbohydrate Polymers, 112: 63-72.

Lobo, V., A. Patil, A. Phatak and N. Chandra (2010). Free radicals, antioxidants and functional foods: Impact on human health. Pharm. Rev., 4: 118-126.

Mercy, T.A. (2015). Qualitative and quantitative analysis of the phytochemicals in some selected species of the genus Phyllanthus in Zaria, Nigeria, 710-711.

Nanna, R.S., M. Banala, A. Pamulaparthi, A. Kurra and S. Kagithoju (2013). Evaluation of Phytochemicals and Fluorescent Analysis of Seed and Leaf Extracts of Cajanus cajan L. Int. J. Pharm. Sci. Rev. and Res., 22 (1): 1118.

Shamsa, F., H. Monsef, R. Ghamooshi and M. Verdian-rizi (2008). Spectrophotometric determination of total alkaloids in some Iranian medicinal plants. Thai. J. Pharm. Sci., 32: $17-20$.

Siddhuraju, P. and S. Manian (2007). The antioxidant activity and free radical scavenging capacity of dietary phenolic extracts from horse gram (Macrotyloma uniflorum (Lam.) Verdc.) seeds. Food Chem., 105 (3): 950-958. 


$$
\begin{aligned}
& \text { التركيب الكيميـائسي وتقــيـر المـواد الفيتـوكيميـائيـة لقثــور البـرتةـــال } \\
& \text { رباب السيد عبدالعظيم ـ حفناوي طه حفناوي } 1 \text { ـ جيهان عبدالله الشوربجي2 }
\end{aligned}
$$

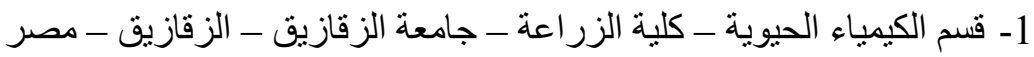

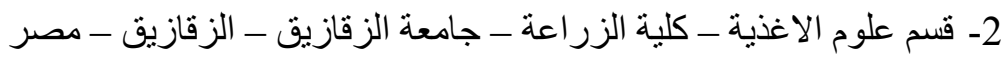

تحليل المواد الكيميائية النباتية النوعية والكمية وتقييم الخصائص المضادة للأكسدة في المختبر للمستخلصات المائية المئية

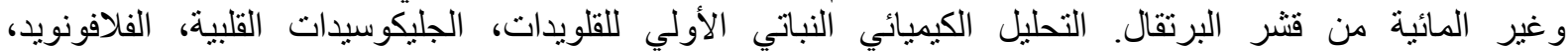

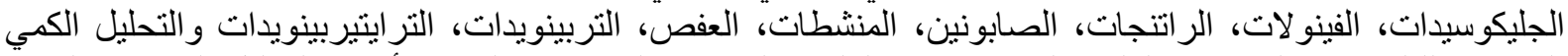

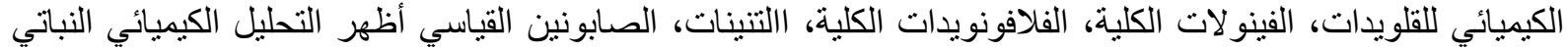

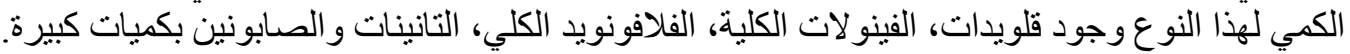

أستاذ التكنولوجيا الحيوية ـ المركز القومي للبحوث ـ القاهرة.

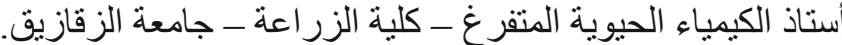

